\title{
1. Rethinking the foundations of macroeconomics
}

\section{Claude Gnos}

\section{INTRODUCTION}

The history of economic thought provides two main approaches to macroeconomics. The first approach, once developed by the classics, aimed at explaining economic phenomena with reference to institutions and to the mode of production prevailing in the economy. The second approach, which became prominent with the triumph of marginalism and the neoclassical school by the end of the nineteenth century, focused on the socalled microfoundations of macroeconomics, that is, individual attitudes and forms of behaviour. With reference to subsequent developments by the so-called new classical school, Hoover (1988, p. 87) characterized the latter approach as follows:

The ultimate goal of the new classical economics is the euthanasia of macroeconomics. ... New classicals believe that only when macroeconomic aggregates are explicable as consequences of well-formulated optimization problems for individuals, i.e. only when complete microfoundations are worked out, will macroeconomic reasoning be secure.

As we know, around 1930 Keynes attempted to renew and promote the classical macrofounded approach to macroeconomics. However, Keynes's attempt has been greatly distorted by his followers. So much so that the viewpoint of present-day Keynesians is close to their neoclassical or new classical counterparts' viewpoint. Their originality only consists of adopting a research programme focusing on wage and price rigidities, whose goal "is to answer the theoretical question of how nominal rigidities arise from optimizing behavior, since the absence of an answer in the 1970s was largely responsible for the decline of Keynesian economics" (Ball et al., 1991, p. 149).

In the next section we consider the case of the 2007 subprime and the ensuing financial crisis, to check the current primacy of the microfounded approach to macroeconomics and its shortcomings. The third section 
examines the way Keynes renewed the classical conception of macrofounded macroeconomics. The fourth section checks the explanatory power of the latter approach, which has been further developed by some writers over the last decades, with reference to inflation, unemployment and financial crisis. The last section concludes.

\section{PRIMACY AND SHORTCOMINGS OF THE MICROFOUNDED APPROACH TO MACROECONOMICS}

What were the causes of the subprime bubble and the ensuing global financial crisis in the first decade of the twenty-first century? Mainstream economists mostly incriminate the forms of behaviour of financial intermediaries, namely those banks and traders that they accused of taking excessive risks on the marketplace. Admittedly, neoclassical economists do not neglect institutions altogether, but according to them institutions simply suffer from imperfections that need to be corrected in order to lead economic agents to serve the general interest. As regards the 2008 global financial crisis, they recommended that prudential rules be strengthened, regulatory and supervisory agencies be made more effective, the transparency of financial operations be enhanced and so on. Notice that the same goes for the problem of unemployment at the time of writing. According to this view, unemployment would result from rigidities in labour markets, intransigence of unions, restricted mobility of workers and high unit labour costs, all features that should be addressed with the neoclassical (neoliberal) agenda.

As a matter of fact, the 2008 global financial crisis is very informative with respect to this way of thinking and its shortcomings. To make our point, it is worth reiterating that mainstream economists were very much confident that liberalized financial markets and the development of new financial instruments and services would allow for an improved allocation of capital worldwide and an effective risk management. Ben Bernanke, when he was the Chairman of the US Federal Reserve, took this logic for granted, as evidenced in his speech at the Federal Reserve Bank of Atlanta's 2007 Financial Market Conference:

The increasing sophistication and depth of financial markets promote economic growth by allocating capital where it can be most productive. And the dispersion of risk more broadly across the financial system has, thus far, increased the resilience of the system and the economy to shocks.

(Bernanke, 2007) 
This was just before the subprime crisis erupted. We all know what actually happened. Rather than endorsing the mainstream thesis, Bernanke should have addressed two main issues that Keynes saw as outstanding faults of the economy in which we live, namely, "its failure to provide for full employment and its arbitrary and inequitable distribution of wealth and income" (Keynes, 1936/2007, p. 372).

Unemployment as well as wealth and income inequalities were notably the key factors of the subprime crisis that burst in 2007: this crisis originated with the huge expansion of mortgage credit in favour of households that could reasonably be suspected to be unable to repay these loans. Why did banks and non-bank financial institutions expand mortgage credit in this context? On the one hand, the US administration fostered this expansion of credit notably by mandating the government-sponsored enterprises Fannie Mae and Freddie Mac to help increasing home ownership, with a view to support the construction sector. On the other hand, and primarily, the creation and development of new financial instruments allowed banks and non-bank financial institutions to spread risks and thus attract private investors. The rise in house prices that resulted from the expansion of mortgage credit complemented the picture: at first it protected investors from losses and allowed borrowers, if necessary, to sell their homes at a gain and repay loans or borrow more.

In other words, these forms of behaviour are just one aspect of the question. Behind them, there is one and the same logic. When the US government fostered lending to households, it did not address income inequalities but promoted measures aimed at supporting the construction sector. Contrariwise, while Keynes argued for supporting demand, he was propounding a change in income distribution characterized by "the euthanasia of the rentier" (Keynes, 1936/2007, p. 376).

All in all, the 2007 subprime crisis shows the urgent need to rethink the foundations of macroeconomics. The nature, aims and features of the whole economic system should be considered anew in the first instance. The mainstream approach leads to disaster and propounds solutions that are at best superficial. The same conclusion holds with regard to policies currently aimed at fighting unemployment, especially across Europe. The keywords, in the latter case, are "flexibility" and "reduction of unit labour costs". As a result, income inequalities grow and domestic demand declines, which means fewer jobs. Germany, contrary to France, has found a way out in export-led growth but with adverse effects on its people's welfare. As China's state authorities that have promoted export-led growth for a long time now acknowledge, this policy cannot be regarded as sustainable over the long run. 


\section{KEYNES'S RENEWED CONCEPTION OF MACROFOUNDED MACROECONOMICS}

Keynes clearly intended to carry forward the banner of classical macroeconomics, especially in the early 1930s, when he opposed the theory of a monetary economy of production he was elaborating to what he named "the real exchange economy" of his contemporaries and immediate predecessors (Keynes, 1933a, 1933b). As proof, we may observe that he referred to Marx's famous M-C-M' formula by which the investment of funds amounts to the transformation of a given sum of money into goods (commodities) and then back into an increased sum of money. In his own words:

[a]n entrepreneur is interested, not in the amount of product, but in the amount of money which will fall to his share. He will increase his output if by doing so he expects to increase his money profit, even though this profit represents a smaller quantity of product than before.

(Keynes, 1933a, p. 82)

He also noticed that " $[t]$ he firm is dealing throughout in terms of sums of money. It has no object in the world except to end up with more money than it started with. That is the essential characteristic of an entrepreneur economy" (Keynes, 1933a, p. 89).

This argument, however, does not amount to endorse Marx's theory that may be seen as an end state of classical macroeconomics. Marx adopted the Ricardian labour theory of value to deepen his understanding of the capitalist mode of production. In this way, he was led to a dead end known as the "transformation problem". In this regard, according to the labour theory of value, the exchange ratio between goods and money - hence the measure of goods in money units - is determined by the labour-values of goods and money, the latter being seen as a good. Exchanges thus take place between equivalent goods (including money). However, Marx had to acknowledge that under pressure of competition and the ensuing equalization of the rates of profit in the various production sectors, price determination would as a rule violate this principle. Finally, the transformation of values into prices could not be explained in a coherent manner. Bortkiewicz (1907, 1952), a Russian economist, put forward a solution to this problem derived from Walras's general equilibrium system of equations, which amounted to discard any relation between Marx's labourvalues and prices, and to co-determinate production costs and prices. A chapter of the history of economic thought was being closed.

By contrast, Keynes's approach remains original. It is based on a renewed analysis of money, which is no more seen as an equivalent coun- 
terpart to goods but as units of account recorded in banks' books and issued when banks grant credit to their clients. In this way, banks do not provide resources on their own, but just credit and debit clients' accounts in their own books, this operation making sense with reference to the actual economic transactions it enables.

Indeed, money's value or purchasing power cannot be defined except with reference to goods currently produced. To support our argument, we may refer to the "finance motive" Keynes defined in his 1937 articles on the interest rate (Keynes, 1937a, 1937b). To start production and pay for the cost of production factors, he argued, firms have to secure "a provision of cash" provided by banks, which "does not absorb or exhaust any resources" but generates new net saving when spent on production: "Each new net investment has new net saving attached to it" (Keynes, 1937a, p. 249). We thereby have a confirmation that banks do not supply purchasing power to firms when financing their factor costs. On the contrary, the payment of factor costs generates new incomes that are saved until their recipients spend them on the market for produced goods and services.

In this way, contrary to Marx, Keynes was able to account for the role of market prices and their variations as regards income distribution. In Marx's theory, profits are created in the production process, in the form of a surplus value produced in excess of the value consumed by workers. This conception allowed Marx to maintain the principle of exchanges of equivalents: workers gain and spend money wages equivalent to the goods they consume. As he pointed out, "[e]very condition of the problem is satisfied, while the laws that regulate the exchange of commodities, have been in no way violated. Equivalent has been exchanged for equivalent" (Marx, 1887, vol. I, p. 102). Hence the transformation problem we have referred to earlier on. In Keynes's theory, profits are formed in product markets when goods are sold at prices higher than the related factor cost. This conception is central to the principle of effective demand, according to which "entrepreneurs will endeavour to fix the amount of employment at the level which they expect to maximise the excess of the proceeds over the factor cost" (Keynes, 1936/2007, pp. 24-5). Defined in this way, profit is a redistributed part of factors' income, transferred from wage earners to firms when prices exceed factor costs. This is a conception that Keynes already outlined in his A Treatise on Money, when explaining that the fall of the selling price of goods below their factor cost would mean a loss for entrepreneurs, causing "a transfer of wealth from the pockets of the entrepreneurs into the pockets of the general public" (Keynes, 1930, p. 159). Profits are simply symmetrical to losses, formed when prices exceed costs.

Although Keynes did not make explicit the idea that profits are incomes transferred from factors' income in his General Theory, we may argue that 
our interpretation is supported by the fact that he considered labour as the sole factor of production, and distinguished two kinds of incomes, the factors' income and the entrepreneurs' income, the latter being dependent on market prices (Keynes, 1936/2007, p. 23). Whether prices are equal or exceed factor cost, the factors (workers) obtain the goods produced in whole or in part when spending their income. A larger or lesser part of their income and its purchasing power on goods is thereby transferred to firms. By the way, to insist on the discrepancy between Keynes's and Marx's analyses, we may notice that the conception of profit we just outlined was strongly dismissed by Marx, who took shots at "the upholders of the delusion that surplus has its origin in a nominal rise of prices or in the privilege which the seller has of selling too dear" (Marx, 1887, p. 85).

\section{MACROFOUNDED ANALYSIS OF INFLATION, UNEMPLOYMENT AND FINANCIAL CRISES}

Keynes elaborated the principle of effective demand with a view to account for unemployment. He put the focus on demand deficiency, which induces entrepreneurs to reduce production. According to the usual Keynesian interpretation of this principle, "fluctuations in employment and output arise largely from fluctuations in nominal aggregate demand. The reason that nominal shocks matter is that nominal wages and prices are not fully flexible" (Ball et al., 1991, p. 149). This interpretation is in line with the search for microfoundations, as we already highlighted. However, it is in plain contradiction to Keynes's own argument that denies any positive effect of variations in wages on employment:

The argument simply is that a reduction in money-wages will cet. par. stimulate demand by diminishing the price of the finished product, and will therefore increase output and employment ... In its crudest form, it is tantamount to assuming that the reduction in money-wages will leave demand unaffected.... It is from this type of analysis that I fundamentally differ.

(Keynes, 1936/2007, pp. 257-8)

Keynes's argument is based on his analysis of the formation and spending of factor's income. Wages fuel demand. To reduce them is to diminish demand accordingly. How could Keynes's followers misinterpret his argument? Much has been said and written about the difficulties Keynes's followers experienced when undertaking to understand the ins and outs of The General Theory (see Samuelson, 1972; Weintraub, 1979). Here, we may simply remind that in order to overcome these difficulties, economists aimed at bridging Keynes's way of thinking and the neoclassical 
theory, which brought about the so-called "neoclassical synthesis". Yet, on Keynes's view, supply and demand involved in the principle of effective demand are not reducible to supply and demand functions adjusting in markets (see Gnos, 2013). In the neoclassical general equilibrium system, supply and demand functions are grounded on the general assumption that productive services exchange for produced goods. It is a question of determining relative quantities and prices that simultaneously ensure the equality of supply and demand of the various goods and services. This is not so in Keynes's view. Supply and demand are functions of employment that, given the wage rate, generates factors' income. Further, there are no demanders and suppliers confronting each other in the marketplace. Supply and demand solely relate to entrepreneurs' expectations. The aggregate demand function represents the entrepreneurs' expectations as to what "the proceeds from sales of the goods they are considering producing and supplying in the market are going to be" (Keynes, 1936/2007, p. 25). By the same token, the supply function represents "the expectation of proceeds which will just make it worth the while of the entrepreneurs to give that employment" (p. 24).

Over the last decades, Keynes's original theory of a monetary economy of production has been revisited by a few writers (see Gnos, 2006), particularly by Bernard Schmitt (see notably Schmitt, 1972 and 1984), who argued that it formed a relevant basis for a renewed macrofounded approach to macroeconomics. Let us check this claim with reference to the analysis of financial crises and unemployment.

With reference to Keynes's finance motive, we noted that the financing of firms' factor cost generates the income of the society as a whole, a part of which will be transferred to firms and form profits when market prices exceed factor cost. Deposited with banks, the factor's income is saved until it is spent on the goods currently produced. Parts of the goods produced are intermediate goods that income holders pay for when they buy the finished consumption goods. Firms also spend money on equipment. In that case, economists and entrepreneurs as well make use of the terms "investment" and "fixed capital". They do so because, contrary to intermediate goods, equipment goods are never bought and consumed by households. They are bought by firms and "fixed" within them. Capital goods incrementally lose their value owing to wear and tear and obsolescence. Consequently, firms meet what Keynes termed "user cost" and have to amortize their fixed capital, that is, periodically replenish its value and replace the corresponding equipment goods.

A priori, it may seem that firms are mere intermediaries in the process of investment and capital replacement. Income holders would save part of their income, that is, not consume part of it, in order to provide firms 
with the funds necessary to purchase the equipment goods they need. They would also pay for the replacement goods. Reality is, however, somewhat more complex. It is true that firms currently borrow money saved by income holders. However, they have to repay loans, which means that, eventually, investment financing comes from firms' own income, to wit, profits, just as when they retain profits and invest them. Replacement goods are as well paid out from profits. Let us examine this issue in more detail.

When earning profits, firms gain a part of the money wages formed in the economy and a share of the corresponding output. It might be argued that firms spend the profit they earn on the corresponding goods that they would have produced in the form of capital goods. However, this argument is flawed. In fact, the formation of profits is a transfer of both money wages and the corresponding goods to firms. Then, it would be nonsense to argue that firms buy goods they already appropriated. As Schmitt concludes, they "can spend these profits in only one way, namely by paying out, in a subsequent period, [the] units of wages for the remuneration of the factors who produce investment goods" (Schmitt, 1996, p. 92). By spending their profits in the payment of workers producing equipment goods, firms appropriate these goods that are thus "fixed" within them. This process has several critical implications.

As a first consequence, the formation of fixed capital generates inflation. This is because the factors producing the equipment goods obtain, in Schmitt's (1984, p. 205) words, "empty wages", that is, wages formed in the production of goods that are already appropriated by firms. Therefore the factors' income is in excess of the goods available on product markets. It is true, however, that the factors may spend these empty wages on the goods that correspond to the profits initially gained by firms and stored by them. In this way, the inflation gap is compensated and neutralized, but the latter is soon renewed without possibility of being offset through the amortization process of firms' fixed capital.

Indeed, as noted earlier, firms have to replenish the value of and replace their equipment goods. To that end, they produce replacement goods and sell consumption goods at a price including the user cost of the former goods. Therefore, the price of consumer goods exceeds their factor cost and the spending of factors' income forms profits to the benefit of firms. These earnings, like any profit, consist of money and goods firms thus appropriate. The money they earn compensate for the factor cost they met in order to produce the replacement goods. In this way, firms appropriate the replacement goods and we may notice that, all in all, the factors producing these goods have received empty wages: they were neither in a position to buy the replacement goods they have produced, nor the profit 
goods firms have appropriated in the process of amortization. The inflation gap initially formed in the investment of firms' profits is thus reiterated and will be so periodically.

However, reiterated inflation is not the sole consequence of fixed capital amortization. We noted that firms appropriate profit goods in the process. Since the corresponding money profits are spent on the replacement goods, there is no money income available in the economy to be spent on these profit goods, contrary to what happens when firms currently earn profits they redistribute to income holders in the form of interests and dividends. This means that firms have no alternative but to anticipate this same formation of profits and produce equipment goods they will incorporate into their fixed capital, in addition to replacement goods. Firms' fixed capital is thus, in Schmitt's words, "duplicated". The value currently lost by fixed capital owing to wear and tear and obsolescence is compensated twice: by amortization and simultaneously by a new investment (for a detailed presentation of the argument, see Schmitt, 1984, pp. 214-23). This process elicits capital over-accumulation. Being a redistributed part of wages, profits cannot be indefinitely increased and their rate decreases. Consequently, we may expect that firms cut investment and produce consumption goods in place of equipment. Unfortunately, amortization cannot do but induce new investment. It generates profit goods appropriated by firms that, as noted earlier, can in no way be sold to consumers since there is no corresponding income available in the economy. In such a situation, firms will meet losses and cut employment. Contrary to common belief, inflation and unemployment are not mutually exclusive. Moreover, we may expect that firms will supply the funds they no longer invest in capital goods on financial markets and in this way play a large part in the build-up of speculative bubbles. It is an escape that carries even more risks for the economy as a whole that actual rates of return on productive capital are decreasing.

Is there a way out? Extending his enquiry to the way monetary and financial operations are currently performed, Schmitt (1984) calls for a structural change in the way banks carry out and record monetary and financial flows and stocks. In this regard, there is no question at all of challenging the crucial role of firms' investment and the correlated amortization process of capital equipment. What is at stake, Schmitt argues, is the way the investment of profits nowadays is recorded in the system of payments and induces inflation, unemployment and financial crises. 


\section{CONCLUSION}

The aim of this chapter was not to deny the fact that forms of behaviour may have far-reaching consequences on economic activity. It was to provide evidence that behaviour, individually and in the aggregate, is enshrined in institutions and economic operations that impose their own logic to it. To that end, we referred to Keynes's macrofounded analysis and recent developments of it, notably by Bernard Schmitt. In this way, we could confirm that inflation, unemployment and speculative bubbles are not just a matter of behaviour and market imperfections, as microfounded macroeconomics suggests.

At the heart of Schmitt's analysis is the distinction between the formation and spending of money income that Keynes already highlighted. Schmitt completes Keynes's analysis by showing that interferences in the spending and the formation of income, which the present-day monetary and financial system allows, are a fundamental cause of economic disorder. Structural factors are thus at work. In this way Schmitt provides an undeniable proof of the relevance of a macrofounded approach to macroeconomics.

\section{REFERENCES}

Ball, L., G. Mankiw and D. Romer (1991), 'The New-Keynesian economics and the output-inflation trade-off', in G. Mankiw and D. Romer (eds), New Keynesian Economics, Cambridge, MA: MIT Press, volume 1, pp. 147-211.

Bernanke, B.S. (2007), 'Regulation and financial innovation', speech at the Federal Reserve Bank of Atlanta's 2007 Financial Markets Conference, 15 May, available at https://www.federalreserve.gov/newsevents/speech/bernanke20070515a. htm; last accessed 8 September 2016.

Bortkiewicz, L. von (1907), 'Zur Berichtung der grundlegenden theoretischen Konstruktion von Marx im dritten Band des Kapital', Jahrbücher für Nationalökonomie und Statistik, July, 319-35.

Bortkiewicz, L. von (1952), 'Value and price in the Marxian system', International Economic Papers, 2, 5-60.

Gnos, C. (2006), 'French circuit theory', in P. Arestis and M. Sawyer (eds), A Handbook of Alternative Monetary Economics, Cheltenham, UK and Northampton, MA, USA: Edward Elgar Publishing, pp. 87-104.

Gnos, C. (2013), 'Monetary production economy versus real exchange economy', in F. Ülgen (ed.), New Contributions to Monetary Analysis, London and New York: Routledge, pp. 122-31.

Hoover, K.D. (1988), The New Classical Macroeconomics: A Sceptical Inquiry, Oxford: Basil Blackwell.

Keynes, J.M. (1930), A Treatise on Money, London: Macmillan, 2 vols.

Keynes, J.M. (1933a), 'A monetary theory of production', in D. Moggridge (ed.) 
(1973), The Collected Writings of John Maynard Keynes, Vol. XIII, London: Macmillan, pp. 408-11.

Keynes, J.M. (1933b), 'The distinction between a co-operative economy and an entrepreneur economy', in D. Moggridge (ed.) (1979), The Collected Writings of John Maynard Keynes, Vol. XXIX, London: Macmillan, pp. 76-106.

Keynes, J.M. (1936/2007), The General Theory of Employment, Interest and Money, London: Palgrave Macmillan.

Keynes, J.M. (1937a), 'Alternative theories of the rate of interest', Economic Journal, 47 (186), 241-52.

Keynes, J.M. (1937b), 'The "ex ante" theory of the rate of interest', Economic Journal, 47 (188), 663-9.

Marx, K. (1887), Capital: A Critique of Political Economy, Vol. I, Moscow: Progress Publishers.

Samuelson, P.A. (1972), The Collected Scientific Papers of Paul Samuelson, Volume II, Cambridge, MA: MIT Press.

Schmitt, B. (1972), Macroeconomic Theory: A Fundamental Revision, Albeuve, Switzerland: Castella.

Schmitt, B. (1984), Inflation, chômage et malformations du capital, Albeuve, Switzerland and Paris: Castella and Economica.

Schmitt, B. (1996), 'Unemployment: is there a principal cause?', in A. Cencini and M. Baranzini (eds), Inflation and Unemployment: Contributions to a New Macroeconomic Approach, London and New York: Routledge, pp. 75-105.

Weintraub, E.R. (1979), Microfoundations: The Compatibility of Microeconomics and Macroeconomics, New York: Cambridge University Press. 